\title{
Adaptations in the calcium and phosphorus metabolism of sheep in response to an intravenous infusion of $\mathbf{C a}$
}

\author{
BY G. D. BRAITHWAITE \\ National Institute for Research in Dairying, \\ Shinfield, Reading, RG2 $9 A T$
}

(Received 27 June 1977 - Accepted 5 September 1977)

I. The effect on calcium and phosphorus metabolism of a high rate of $\mathrm{Ca}$ infused directly into the blood of Ca-deficient wethers, already receiving an adequate $\mathrm{Ca}$ intake, has been studied by a combination of balance and radioisotope techniques.

2. The rate of $\mathrm{Ca}$ retention, which was already high, increased only slightly during the infusion before it reached a maximum. The surplus $\mathrm{Ca}$ was compensated for by a decrease in the rate of absorption and an increase in the rate of urinary $\mathrm{Ca}$ excretion.

3. These findings support the theory that at maximum retention the rate of $\mathrm{Ca}$ absorption becomes regulated according to the rate at which $\mathrm{Ca}$ can be stored in bone.

4. Results suggest that the decreased absorption was due to a decrease in the rate of active absorption and that the low rate remaining was due to diffusion.

5. The rate of $\mathrm{P}$ retention was increased by the $\mathrm{Ca}$ infusion, possibly as a result of the increased $\mathrm{Ca}$ retention.

In the sheep increased retention of calcium is brought about by a decrease in the rate of bone resorption and the rate of bone accretion remains constant (Braithwaite, 1974, 1975). In the $\mathrm{Ca}$-deficient wether maximum retention of $\mathrm{Ca}$ occurs just as bone resorption ceases and is equal to the rate of bone accretion (Braithwaite, 1975). Since the rate of absorption of $\mathrm{Ca}$ from the intestine reaches a constant value at exactly the same time as retention becomes maximal, it has been suggested that $\mathrm{Ca}$ absorption is regulated according to the rate at which $\mathrm{Ca}$ can be stored in bone (Braithwaite, 1975). The maximum rate of $\mathrm{Ca}$ absorption possible is then equal to the rate of irreversible loss of $\mathrm{Ca}$ from the rapidly exchangeable pool. This regulation of $\mathrm{Ca}$ absorption at maximum retention appears also to occur in Ca-deficient lactating ewes (Braithwaite, 1978).

The relationship between $\mathrm{Ca}$ absorption, maximum $\mathrm{Ca}$ retention and the rate of bone accretion has now been investigated in an experiment in which a higher rate of $\mathrm{Ca}$ absorption than that thought to be needed for maximum retention was simulated by the infusion of calcium chloride directly into the blood of $\mathrm{Ca}$-deficient sheep, now maintained on a diet adequate in $\mathrm{Ca}$.

\section{EXPERIMENTAL}

Animals, housing and diet

Five 3-year-old Suffolk wethers weighing $60-70 \mathrm{~kg}$ were used. They were housed in metabolism cages designed for the separate collection of urine and faeces and had free access to distilled water. They were given a low-Ca basal diet of hay and concentrates (Table I) which supplied $27.3 \mathrm{mg} \mathrm{Ca} / \mathrm{d}$ per $\mathrm{kg}$ body-weight and $57.9 \mathrm{mg} \mathrm{P} / \mathrm{d}$ per $\mathrm{kg}$ body-weight. Although the $P$ intake was about adequate to supply maintenance requirements (Agricultural Research Council, 1965; National Research Council, 1968), the Ca intake was considerably less than the $55 \mathrm{mg} / \mathrm{d}$ per $\mathrm{kg}$ body-weight calculated from results of Braithwaite \& Riazuddin, (I97I) as necessary for maintenance. During the experimental period, the basal diet was supplemented with calcium carbonate so that the new $\mathrm{Ca}$ intake (103.3 $\mathrm{mg} / \mathrm{d}$ per $\mathrm{kg}$ body-weight) was much greater than that needed for maintenance. 
Table I. Composition, calcium and phosphorus content of the low-Ca basal diet* given daily to 3-year-old wether sheep

$\begin{array}{lccccc}\text { Ingredient } & \begin{array}{c}\text { Amount } \\ \text { (g/kg body-wt) }\end{array} & \begin{array}{c}\text { Ca content } \\ (\mathrm{mg} / \mathrm{g})\end{array} & \begin{array}{c}\text { Total Ca } \\ (\mathrm{mg} / \mathrm{kg} \text { body-wt) }\end{array} & \begin{array}{c}\text { P content } \\ (\mathrm{mg} / \mathrm{g})\end{array} & \begin{array}{c}\text { Total P } \\ (\mathrm{mg} / \mathrm{kg} \text { body-wt) }\end{array} \\ \text { Hay } & 5 & 4.30 & 21 \cdot 5 & 2.19 & 10.9 \\ \text { Barley } & 5 & 0.56 & 2.8 & 4.40 & 22 \cdot 0 \\ \text { Maize } & 2.5 & 0.03 & 0 . \mathrm{I} & 1.56 & 3.9 \\ \text { Bran } & 1.25 & 0.16 & 0.2 & 13.02 & 16.3 \\ \text { Linseed-oil cake } & 0.5 & 3.19 & 1.6 & 9.26 & 4.6 \\ \text { Vitamint } & 0.07 & 15.70 & 1 \cdot 1 & 2.20 & 0.2 \\ \text { Whole diet } & & & 27.3 & & 57.9\end{array}$

* During the experimental period $\mathrm{CaCO}_{3}$ was added to the basal diet to supply an additional $76 \mathrm{mg} \mathrm{Ca} / \mathrm{kg}$ body-wt.

$\dagger$ Beta Vitamin No. 3a (Cooper Nutrition Products Ltd, Witham, Essex) to supply $37.5 \mu \mathrm{g}$ retinol equivalent and $0.775 \mu \mathrm{g}$ cholecalciferol $/ \mathrm{kg}$ body-wt.

\section{Experimental design}

All animals were given the low-Ca basal diet for 3 months before the start of the experiment to ensure that their skeletal stores were deficient in Ca (Braithwaite, 1974). They were then randomly divided into two groups and both groups were given the dietary supplement of $\mathrm{CaCO}_{3}$. In addition, the experimental group was given an infusion of a solution of $\mathrm{CaCl}_{2}$ into a jugular vein. This infusion started $3 \mathrm{~d}$ after the dietary supplementation and lasted for a period of $\mathrm{I} 2 \mathrm{~d}$.

The amount of $\mathrm{Ca}$ that must be absorbed by $\mathrm{Ca}$-deficient wethers for maximum retention is equal to the total irreversible loss of $\mathrm{Ca}$ from the rapidly exchangeable pool (Braithwaite, 1975, 1978). This loss of $\mathrm{Ca}$, which occurs by excretion in the urine, secretion into the intestine and accretion into bone, can be estimated from results of Braithwaite \& Riazuddin (1971) at approximately $50 \mathrm{mg} / \mathrm{d}$ per $\mathrm{kg}$ body-weight for a 3-year-old wether. The $\mathrm{CaCl}_{2}$ solution $(28 \mathrm{mg} \mathrm{Ca} / \mathrm{ml})$ was infused at such a rate $(50 \mathrm{mg} / \mathrm{d}$ per $\mathrm{kg}$ body-weight) that the total input of $\mathrm{Ca}$ into the rapidly exchangeable pool by intestinal absorption and infusion together was greater than that required for maximum retention.

Eight days after the start of the $\mathrm{CaCO}_{3}$ supplementation (or $5 \mathrm{~d}$ after the start of the $\mathrm{Ca}$ infusion) Ca kinetic studies were made. A known amount $(5 \mu \mathrm{Ci} / \mathrm{kg}$ body-weight) of an aqueous solution of ${ }^{45} \mathrm{CaCl}_{2}$ (Radiochemical Centre, Amersham, Bucks) was injected into a jugular vein and samples of blood, urine and faeces were collected for a period of $\mathrm{I}$ week as previously described (Braithwaite, Glascock \& Riazuddin, 1969). During this period Ca-balance measurements were made. Both groups of animals were then returned to the low-Ca basal diet for I month after which the treatments were reversed and the $\mathrm{Ca}$ kinetic studies repeated.

\section{Methods}

Kinetic analysis was done by the method of Aubert \& Milhaud (1960) modified for use with sheep (Braithwaite et al. 1969; Braithwaite \& Riazuddin, 197I). The methods used for the determination of $\mathrm{Ca}, \mathrm{P}$ and radioactivity, in samples of blood, urine, faeces and food have been described previously (Braithwaite et al. 1969; Braithwaite, 1975).

\section{RESULTS AND DISCUSSION}

Results given in Table 2 show that when $\mathrm{Ca}$ was infused directly into the blood of $\mathrm{Ca}$ deficient wethers, already receiving an adequate intake of $\mathrm{Ca}$, the rate of $\mathrm{Ca}$ retention was increased by only a small amount $(+I 2.9 \mathrm{mg} / \mathrm{d}$ per $\mathrm{kg}$ body-weight) compared with the 
Table 2. A comparison of the calcium and phosphorus metabolism of 3-year-old Ca-deficient wethers receiving either an adequate $\mathrm{Ca}$ intake or an adequate $\mathrm{Ca}$ intake plus an infusion of a solution of $\mathrm{CaCl}_{2}$ into the jugular vein.

(Mean values for five sheep)

\begin{tabular}{|c|c|c|c|c|}
\hline $\begin{array}{l}\text { Rate of ingestion of } \mathrm{Ca}(\mathrm{mg} / \mathrm{d} \text { per } \mathrm{kg} \\
\text { body-wt) }\end{array}$ & $102 \cdot 5$ & $98 \cdot 5$ & $3 \cdot 1$ & NS \\
\hline $\begin{array}{l}\text { Rate of loss of } \mathrm{Ca} \text { in faeces }(\mathrm{mg} / \mathrm{d} \text { per } \\
\mathrm{kg} \text { body-wt) }\end{array}$ & $80 \cdot 7$ & $99 \cdot 7$ & $3 \cdot 7$ & ** \\
\hline $\begin{array}{l}\text { Rate of excretion of } \mathrm{Ca} \text { in urine }(\mathrm{mg} / \mathrm{d} \\
\text { per } \mathrm{kg} \text { body-wt) }\end{array}$ & $1 \cdot 7$ & $16 \cdot 7$ & 0.8 & $* * *$ \\
\hline Rate of $\mathrm{Ca}$ retention ( $\mathrm{mg} / \mathrm{d}$ per $\mathbf{k g}$ body-wt) & $+20 \cdot I$ & $+33 \cdot 0$ & $I \cdot 8$ & $* *$ \\
\hline $\begin{array}{l}\text { Rate of secretion of } \mathrm{Ca} \text { into intestine (faecal } \\
\text { endogenous } \mathrm{Ca})(\mathrm{mg} / \mathrm{d} \text { per } \mathrm{kg} \text { body-wt) }\end{array}$ & $8 \cdot 7$ & $9 \cdot 2$ & 0.5 & NS \\
\hline $\begin{array}{l}\text { Rate of absorption of Ca from intestine } \\
(\mathrm{mg} / \mathrm{d} \text { per } \mathrm{kg} \text { body-wt) }\end{array}$ & $30 \cdot 5$ & $8 \cdot 0$ & $\mathrm{I} \cdot 3$ & $* * *$ \\
\hline $\mathrm{Ca}$ absorbed (\% $\mathrm{Ca}$ ingested) & $29 \cdot 8$ & $8 \cdot I$ & $I \cdot 6$ & *** \\
\hline Rate of $\mathrm{Ca}$ infusion (mg/d per $\mathrm{kg}$ body-wt) & - & 50.9 & & \\
\hline $\begin{array}{l}\text { Rapidly exchangeable pool of } \mathrm{Ca}(\mathrm{mg} / \mathrm{kg} \\
\text { body-wt) }\end{array}$ & $43 \cdot 9$ & $50 \cdot 0$ & I.9 & $*$ \\
\hline $\begin{array}{l}\text { Slowly exchangeable pool of } \mathrm{Ca} \text { in bone } \\
(\mathrm{mg} / \mathrm{kg} \text { body-wt) }\end{array}$ & $68 \cdot 2$ & $75 \cdot 4$ & $4 \cdot 0$ & NS \\
\hline $\begin{array}{l}\text { Rate of accretion of } \mathrm{Ca} \text { into bone }(\mathrm{mg} / \mathrm{d} \\
\text { per } \mathrm{kg} \text { body-wt) }\end{array}$ & $36 \cdot 4$ & $36 \cdot 1$ & $\mathbf{I} \cdot \mathbf{2}$ & NS \\
\hline $\begin{array}{l}\text { Rate of resorption of } \mathrm{Ca} \text { from bone }(\mathrm{mg} / \mathrm{d} \\
\text { per } \mathrm{kg} \text { body-wt) }\end{array}$ & 16.3 & $3 \cdot I$ & $2 \cdot 2$ & ** \\
\hline Serum $\mathrm{Ca}(\mathrm{mg} \%)$ & $9 \cdot 9$ & $11 \cdot 4$ & 0.4 & * \\
\hline $\begin{array}{l}\text { Rate of ingestion of } P(\mathrm{mg} / \mathrm{d} \text { per } \mathrm{kg} \\
\text { body-wt) }\end{array}$ & $55 \cdot 6$ & $54 \cdot 5$ & 0.4 & NS \\
\hline $\begin{array}{l}\text { Rate of loss of } \mathbf{P} \text { in faeces ( } \mathrm{mg} / \mathrm{d} \text { per } \mathrm{kg} \\
\text { body-wt) }\end{array}$ & $46 \cdot 0$ & $30 \cdot 7$ & $2 \cdot 8$ & ** \\
\hline $\begin{array}{l}\text { Rate of excretion of } P \text { in urine (mg/d per } \\
\mathrm{kg} \text { body-wt) }\end{array}$ & $2 \cdot 0$ & $2 \cdot 0$ & 0.9 & NS \\
\hline $\begin{array}{l}\text { Apparent } P \text { absorption ( } P \text { ingested }-P \text { lost } \\
\text { in faeces) (mg/d per } \mathrm{kg} \text { body-wt) }\end{array}$ & $9 \cdot 6$ & $23 \cdot 8$ & $2 \cdot 9$ & $* *$ \\
\hline Rate of $\mathrm{P}$ retention (mg/d per $\mathrm{kg}$ body-wt) & $+7 \cdot 6$ & $+21 \cdot 8$ & $2 \cdot 5$ & $* *$ \\
\hline
\end{tabular}

\begin{tabular}{|c|c|c|c|}
\hline \multicolumn{2}{|c|}{ Adequate $\mathrm{Ca}$ intake } & \multirow{2}{*}{$\begin{array}{c}\text { error } \\
\text { (residual } \\
\text { mean } \\
\text { square) }\end{array}$} & \multirow{2}{*}{$\begin{array}{c}\text { the } \\
\text { difference } \\
\text { between } \\
\text { means }\end{array}$} \\
\hline No infusion & $+\mathrm{Ca}$ infusion & & \\
\hline 102.5 & 98.5 & $3 \cdot I$ & NS \\
\hline
\end{tabular}

\begin{tabular}{|c|c|}
\hline $\begin{array}{l}\text { Standard } \\
\text { error } \\
\text { (residual } \\
\text { mean } \\
\text { square) }\end{array}$ & $\begin{array}{c}\text { Significance of } \\
\text { the } \\
\text { difference } \\
\text { between } \\
\text { means }\end{array}$ \\
\hline $3 \cdot I$ & NS \\
\hline 3.7 & ** \\
\hline 0.8 & $* * *$ \\
\hline$I \cdot 8$ & $* *$ \\
\hline 0.5 & NS \\
\hline I & $* * *$ \\
\hline
\end{tabular}

total amount of $\mathrm{Ca}$ infused $(50.9 \mathrm{mg} / \mathrm{d}$ per $\mathrm{kg}$ body-weight). This result is not unexpected, however, as it has previously been shown that maximum retention of $\mathrm{Ca}$ occurs when bone resorption ceases (Braithwaite, 1974, 1975). Since bone resorption was already low in animals receiving the $\mathrm{CaCO}_{3}$ supplement, only a slight fall was possible during the infusion before maximum retention occurred.

The remainder of the infused $\mathrm{Ca}$, was compensated for by a combination of a decrease in the rate of $\mathrm{Ca}$ absorption $(-22.5 \mathrm{mg} / \mathrm{d}$ per $\mathrm{kg}$ body-weight) and an increase in the rate of urinary $\mathrm{Ca}$ excretion ( $+15 \mathrm{mg} / \mathrm{d}$ per $\mathrm{kg}$ body-weight). A decrease in absorption has also been observed by other workers in cows made hypercalcaemic by the intravenous infusion of Ca (Ramberg \& Kronfeld, I97I). Such a change in the rate of absorption of Ca adds support to the theory of Braithwaite $(1975,1978)$, that absorption by Ca-deficient sheep receiving an adequate $\mathrm{Ca}$ intake is regulated by homoeostatic mechanisms at a level just sufficient for maximum retention.

$\mathrm{Ca}$ absorption is now generally regarded as involving two processes, a non-saturable 
diffusional one, related to intestinal $\mathrm{Ca}$ concentration and a saturable active one, independent of concentration but regulated according to body needs (Wasserman \& Taylor, I969; Braithwaite, 1974). Since the dietary intake of Ca remained constant in the present experiments, the decrease in absorption rate must have been due to a decrease in active transport rather than diffusion. Furthermore, since this decrease did not compensate for all the surplus $\mathrm{Ca}$, the low rate of absorption remaining may not be under endocrine control and may represent that $\mathrm{Ca}$ absorbed by passive diffusion alone. The time (I week) required by these $\mathrm{Ca}$-deficient wethers for adaptation of the active component of $\mathrm{Ca}$ absorption to the increased $\mathrm{Ca}$ input contrasts with that (6 weeks) required by Ca-replete wethers transferred from a normal to a high $\mathrm{Ca}$ intake (Braithwaite, 1974). The rapid rate of response, however, may merely reflect the very large surplus of $\mathrm{Ca}$ input to that required for maximum retention. The mechanism involved in this adaptation was probably triggered by the resulting increase in serum $\mathrm{Ca}$ concentration (Table 2), which as is well known, sets in motion a train of events which involves a decreased secretion of parathyroid hormone and an increased secretion of calcitonin, a decreased secretion of 1,25 -dihydroxycholecalciferol and finally a decreased rate of active absorption of Ca (Care, 1969; DeLuca, 1974, 1975; Braithwaite, 1976).

It is of interest that the rate of secretion of $\mathrm{Ca}$ into the intestine was not altered by the infusion, especially as there is evidence from work with non-ruminants that it is directly related to the serum $\mathrm{Ca}$ concentration (Gran, I960; Toverud, 1964). Such a relationship, however, has never been confirmed in ruminants (Braithwaite, I974; Ramberg, Mayer, Kronfeld, Phang \& Berman, 1970).

Although the size of the rapidly exchangeable $\mathrm{Ca}$ pool and the slowly exchangeable bone pool were both increased slightly by the infusion, the increase in the bone pool was not significant. Since the rapidly exchangeable pool includes the $\mathrm{Ca}$ of the blood, the slight increase in its size is not unexpected.

The rates of apparent absorption and retention of $\mathrm{P}$ were both increased by the $\mathrm{Ca}$ infusion even though the $\mathrm{P}$ intake was unaltered. Since the rate of secretion of $\mathrm{P}$ into the intestine was not measured, it is not possible to decide whether the increased rate of apparent absorption was due to an increase in true absorption or to a decrease in secretion. However, since dietary $P$ is normally absorbed in direct relation to the $P$ intake and the excess is secreted back into the gastro-intestinal tract (Preston \& Pfander, 1964; Young, Lofgreen \& Luick, 1966; Young, Richards, Lofgreen \& Luick, 1966), it seems likely that the increased retention was due to decreased secretion and was related to the higher rate of retention of $\mathrm{Ca}$. Certainly results of previous experiments with $\mathrm{Ca}$-deficient wethers suggest that $\mathrm{Ca}$ and $\mathrm{P}$ are retained in a constant ratio and that $\mathrm{P}$ retention is controlled according to the rate of $\mathrm{Ca}$ retention (Braithwaite, 1975).

\section{Ca homoeostasis}

These results illustrate the very strict control of $\mathrm{Ca}$ metabolism in the ruminant. $\mathrm{Ca}$ absorption is normally controlled according to skeletal requirements (Braithwaite, Glascock \& Riazuddin, 1970; Braithwaite, 1974). When this control was circumvented by the infusion of $\mathrm{Ca}$ directly into the blood of the $\mathrm{Ca}$-deficient sheep at such a rate that the total input into the exchangeable pool was much more than that necessary for maximum requirements, rapid adaptation took place, and homoeostasis was maintained. This adaptation involved a decrease in the rate of bone resorption to a negligible level, a decrease in the rate of active absorption of $\mathrm{Ca}$, possibly also to a negligible level and finally an increase in the rate of urinary $\mathrm{Ca}$ excretion. The rate of accretion of $\mathrm{Ca}$ into bone, however, remained unaltered. 
I thank Dr R. F. Glascock for his encouragement, Mrs A. F. A. Jones, Miss S. C. Neville and $\mathrm{Mr}$ R. J. Ranson for skilled technical assistance and $\mathrm{Mr}$ A. R. Jones for the care and maintenance of the experimental animals.

\section{REFERENCES}

Agricultural Research Council (1965). The Nutrient Requirements of Farm Livestock, no. 2, Ruminants. London: H.M. Stationery Office.

Aubert, J.-P. \& Milhaud, G. (1960). Biochim. biophys. Acta 39, 122.

Braithwaite, G. D. (1974). Br. J. Nutr. 31, 319.

Braithwaite, G. D. (1975). Br. J. Nutr. 34, 31 I.

Braithwaite, G. D. (1976). J. Dairy Res. 43, 501 .

Braithwaite, G. D. (1978). Br. J. Nutr. 39, 213.

Braithwaite, G. D., Glascock, R. F. \& Riazuddin, Sh. (1969). Br. J. Nutr. 23, 827.

Braithwaite, G. D., Glascock, R. F. \& Riazuddin, Sh. (1970). Br. J. Nutr. 24, 66I.

Braithwaite, G. D. \& Riazuddin, Sh. (197I). Br. J. Nutr. 26, 2 I 5.

Care, A. D. (1969). Proc. Nutr. Soc, 28, 183.

DeLuca, H. F. (1974). Fed. Proc. 33, 221 I.

DeLuca, H. F. (1975). Acta orthop. scand. 46, 286.

Gran, F. C. (1960). Acta Physiol. scand. 48, Suppl. 167.

National Research Council (1968). Publs. natn. Res. Counc., Wash. no. I 693.

Preston, R. L. \& Pfander, W. H. (1964). J. Nutr. 83, 369.

Ramberg, C. F. Jr \& Kronfeld, D. S. (1971). J. Dairy Sci. 54, 794.

Ramberg, C. F. Jr, Mayer, G. P., Kronfeld, D. S., Phang, J. M. \& Berman, M. (1970). Am. J. Physiol. 219, I 66.

Toverud, S. U. ( I 964). Acta Physiol. scand. 62, Suppl. 234.

Wasserman, R. H. \& Taylor, A. N. (1969). In Mineral Metabolism, vol. 3, ch. 5 [C. L. Comar and F. Bronner, editors]. New York and London: Academic Press.

Young, V. R., Lofgreen, G. P. \& Luick, J. R. (1966). Br. J. Nutr. 20, 795.

Young, V. R., Richards, W. P. C., Lofgreen, G. P. \& Luick, J. R. (1966). Br. J. Nutr. 20, 783. 